\title{
30 A Tibetan Image of Divination: Some Contextual Remarks
}

\author{
Ronit Yoeli-Tlalim
}

This paper will focus on a Tibetan image of divination found in the Wellcome Images collection (no. Loo35124, Fig. 1), ${ }^{1}$ illustrating the close association between divination and medicine as taught and practised in the Tibetan medical tradition.

The present contribution will link some of the visual imagery found in this illustration with some of its corresponding theoretical considerations and practical applications. I will focus here on two main motifs in the Wellcome image: the turtle and the magic square. I shall look at some similarities between the Tibetan and Chinese notions illustrated in this Wellcome image, as well as a parallel from the Ilkhanid court in Iran.

The material under discussion provides us with an intriguing case study of how ideas of medicine and divination change as they move between different cultural contexts. This material allows also to reflect on some of the connections between images and knowledge on-themove, and contributes another angle to one of the grand questions which this volume addresses as a whole, namely the role of images in contributing to our understanding of transmissions of medical knowledge.

When looking at the links between medicine and divination in a cross-cultural perspective, one finds many striking similarities in a variety of Euro-asian cultures, in spite of their adoption into very different cultural contexts. ${ }^{2}$ Recent research, primarily of a collaborative nature, has revealed that many of these similarities are due to multi-faceted networks of transmission of knowledge. ${ }^{3}$ Research into these networks is slow and complex. Analysing visual representations of some of these transmitted notions is one prism which can allow glimpses into cultural traces, traces which might otherwise be easily ignored or marginalised. ${ }^{4}$

Most of the theoretical concepts depicted in the central figure of this image are derived from Chinese notions. This specific visual compilation, however, like the very similar

1 Research for this chapter was supported by the Islam and Tibet Project (2005-7, funded by the AHRC) and the Wellcome Trust (2007-10, Tibetan Medicine: A Himalyan Melange, grant no. o76159).

2 See Akasoy, Burnett and Yoeli-Tlalim (eds) 2008. For an overview of similarities, see the editors' Preface, pp. ix-xii.

On these networks in the ancient world, see Mair 2006.

For Edward Said's discussion of Gramsci's notion of traces, see Said 2003 [1978], p. 25.

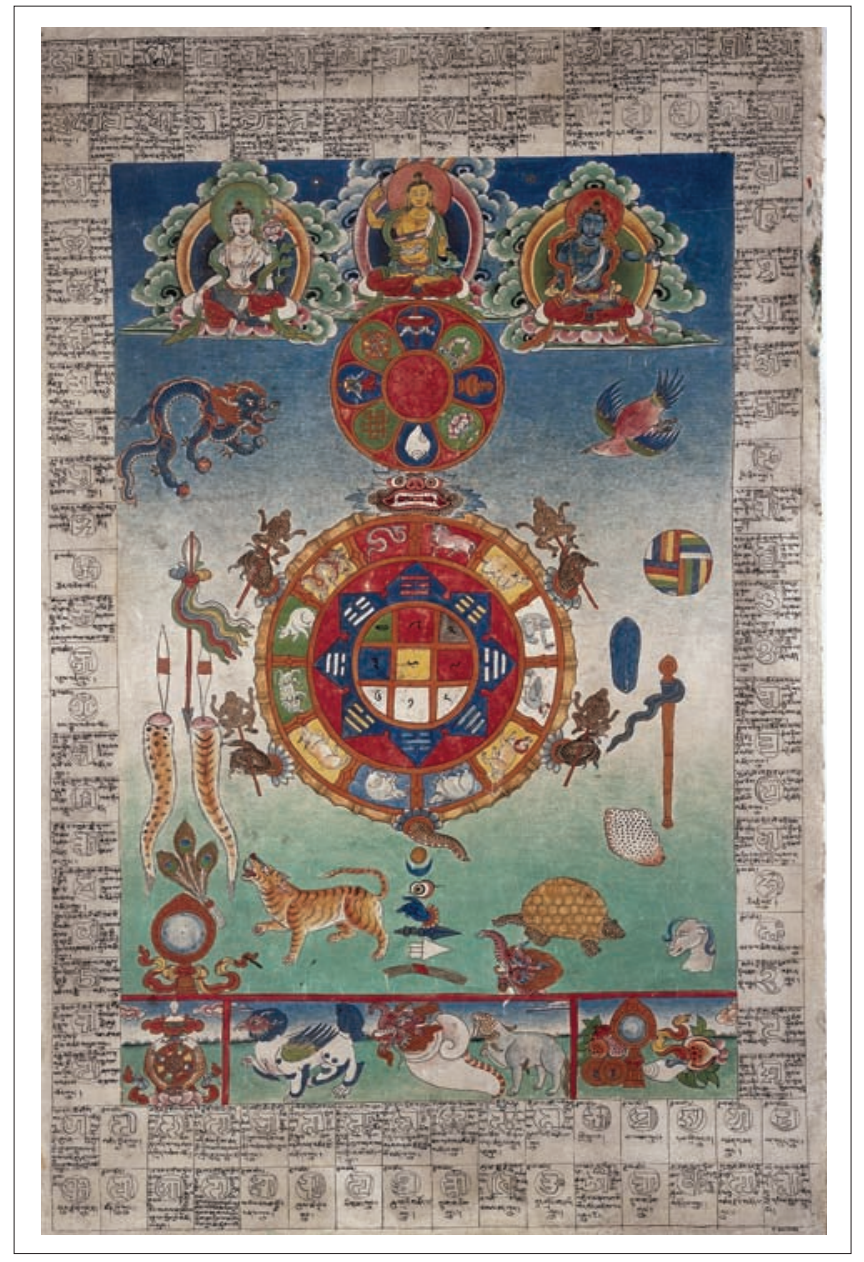

Figure 30.1 A Tibetan Protection painting containing the main elements of Tibetan divination. Tibet, 19th century. (C) Wellcome Library, London, Oriental Tibetan 114, Loo35124

and hugely popular Tibetan charts known as sridpa ho, is specifically Tibetan.

The central motif of this image is of a large turtle, with a magic square of nine (sme ba dgu) in its midst. Surrounding it are the eight trigrams (spar kha brgyad). These are surrounded by a depiction of the 12-year cycle (lo skor bcu nyis). Below the turtle, we find a depiction of the seven-day planet week. The entire image is presided over by Buddhist deities, while Buddhist auspicious symbols are depicted around the main image. Surrounding the image are 104 squares containing instructions for making amulets, which are to be written on a piece of cloth. The image as a whole can be seen as a kind of visual summary of the key elements which stand at the heart of Tibetan medical divination. The overall composition of this image 
is arranged like a mandala, one of the most common visual images in Vajrayāna Buddhism.

\section{Tibetan Medical Divination - General Contextualisation $^{5}$}

Astrology, time computation and divination (rtsis) have been part of Tibetan medicine throughout its history. ${ }^{6}$ In Tibetan, the term rtsis, which is usually translated as 'astrology', refers to astronomy, time computation and divination. The astral sciences are further divided into what is usually translated as 'elemental astrology' ('byung rtsis) and astronomy/astrology (skar rtsis). 'Byung rtsis, also known as 'Chinese divination' (nagrtsis), refers to the system of divination based on concepts found in Chinese divination: the relationships formed between the five agents (Wood, Fire, Earth, Metal and Water) and their various representations, the 12 animal signs, the trigrams (sparkha) and numeric squares (sme ba).

In his explanation of why the science of the stars (skar rtsis) is so central to the healing arts, Sangye Gyatso (Sangs rgyas rya mtsho, 1653-1705), Regent of the Fifth Dalai Lama, to whom a number of important books on medicine and on divination are accredited, explains:

Using it one calculates the times, directions, and dates when the collecting, preparation, and taking of medicines becomes effective and auspicious. There is a great difference between these benefits and the disastrous consequences that come from not knowing this astrology (skar rtsis).

Black [or, elemental] calculation is so called because it spread from the country of black clothes (i.e. China). It describes pulse evaluation - calculating mother, son, enemy, and friend pulses - and urine analysis in conjunction with turtle diagrams and so on, topics that are of prime interest for medical literature. It also covers subjects such as karma calculation, which can predict lifespans and foretell whether one will survive an illness without medical intervention. It deals with the examination of the year, month, day, and hour to divine whether various therapies are appropriate and to calculate the auspicious and inauspicious times for compounding medicines, for performing various medical practices, and so on. It also covers the consulting of land guardians to divine auspicious and inauspicious directions. In particular, using

This overview is based on Yoeli-Tlalim 2014.

For an overview on Tibetan sources on astrology and time computation, see Schuh 1973, pp. 22-46; Dorje 2001. For an illuminating work on Kālacakra time computation, see Henning 2007. On Tibetan divination, see Stein 1939; Jhampa Kalsang 1999; Chime Radha Rinpoche 1981; Jampa Dagthon et al 1998; Cornu 1997; Laufer 1914. only illness divination and time divination, you can make prognoses and learn which demon is causing the illness and what rituals are to be performed, all without resorting to guesswork or relying on other forms of divination, oracles, and the like. In this way elemental calculation has a very strong connection with medical science. ${ }^{7}$

Medicine and astrology have been closely interlinked in Tibet, theoretically, practically and institutionally. Both medicine and astrology have been taught together at medical colleges. To this day, Tibetan doctors are required to study astrology as part of their training. Indeed the two main Tibetan medical colleges, in Lhasa and in Dharamsala, are both called sMan-rtsis-khang (Institute of Medicine and Astrology).

Divination has played - and still plays - a very significant role in all levels of Tibetan society. ${ }^{8}$ Calculations of the relationships formed by the five elements are frequently applied in all parts of life such as birth, marriage, detecting obstacles, analysing disease, analysing spiritual progress and foretelling death. There are various types of auspicious and inauspicious dates, which are marked on every Tibetan calendar. The waxing half of Tibetan lunar months is considered in general more auspicious than the waning half. Therefore, most Tibetans will begin constructive, positive practices during the first half of the lunar month.

Astrological divination of illness constitutes a major part of divination practices in general. These practices, assigned to an astrologer rather than a doctor, are discussed especially in relation to cases where the patient is not seen to respond to medical treatment. Some of the topics examined within this context include: the degree to which the life-spirit or lifespan has been dissipated; the degree to which one is pursued or exploited by malevolent forces; the degree to which the 'heavenly life-line' has been cut, and others. ${ }^{9}$

Divination is also used in the medical context in order to determine the existence of what is termed 'spirit-inflicted illnesses'. These are illnesses that are otherwise unexplained, which are attributed to nine types of spirits. Various divination methods for diagnosing such illnesses are described in the medical writings. It is said that in order to treat the illness, it is necessary to identify which type of spirit is causing the affliction. These divination

\footnotetext{
7 Sangs rgyas rgya mtsho, tr. Kilty 2010, pp. 453-4.

8 For an account of current uses of Tibetan astrology and divination in medical contexts, see Vasstveit 2014.

9 Divination of illness is discussed in Sangs rgyas rgya mtsho, Phug lugs rtsis kyi legs bshad Vaidūra dkar po, 1972 edn, I, fols 556-6o7 (original pagination: fols $274 \mathrm{r}-299 \mathrm{v}$ ). For a translation of these chapters, see Dorje 2001, pp. 294-305.
} 
methods include urine divination and observing seasonal influences on pulse diagnosis..$^{10}$

According to Tibetan medicine, since the seasons have an effect on the pulse and since each season has its activity pattern, a doctor needs to know the exact time of the season in order to be able to read the pulse correctly. Of a more divinatory nature are the 'seven astonishing pulses', which are based on the mother-son and friend-enemy relationship between the five agents and the patient's organs, as delineated in Chinese divination. Based on those, a doctor is described as being able to read from the pulse information regarding the patient's family, guests, enemies, finances, relationship with spirits, prospects and procreative fate. ${ }^{11}$ Other topics of astro-medicine include the collection of medicinal herbs and the preparation of medicines, which need to be performed in accordance with certain astrological events, as well as the association between the days of the week and the planets and the medical implications that they entail. As with medicine more generally, Tibetan astro-medicine is derived from several cultural contexts: predominantly Indian, Chinese and indigenous, codified within an overall Buddhist context. ${ }^{12}$

\section{China as the Land of Divination in Tibetan Sources}

Tibetan sources often refer to China as the land of divination'. A popular saying in Tibet maintains this connection: 'cho (religious doctrine) came from India and tsi (astrology) from China'.13

According to some Tibetan accounts, Songtsen Gampo brought to Tibet knowledge from the four great countries surrounding it. Pawo tsuglag (dpa'bo gtsug lag, 1504-66), for example, tells us:

In the east, from China and Minyak, he took books of technology and of divinatory calculation (others say: medicine and calculations) of the five elements. ${ }^{14}$

The section dealing with pulse diagnosis appears in the rGyud bzhi, Phyi ma rgyud (subsequent Tantra), ch. 1. bDud rtsi snying po yan lag brgyad pa gsang man ngag gi rgyud, Lhasa, 2000 edn, pp. 557-67. For an English translation, see Yuthok Yonten Gonpo, tr. Thokmay Paljor et al. 2011. See also Parfionovitch, Dorje and Meyer 1992, pls, pp. 123-39.

11 Parfionovitch, Dorje and Meyer 1992, pls, pl. 55, pp. 125-6.

12 See Yang Ga 2014.

13 Chime Radha Rinpoche 1981, pp. 6-7.

14 Quoted in Stein 1972, p. 52, n. 2. See also Chime Radha Rinpoche 1981, pp. 6-7.
Tibetan sources distinguish between two strands of Chinese divination teachings: an older strand of Chinese divination (rgya rtsis rnying ma) and a later one (rgya rtsis gsar ma), which was introduced from the 17 th century onwards. ${ }^{15}$

While the later strand has received scholarly attention - primarily through Gyurme Dorje's monumental work on Sangs rgyas rgya mtsho's treatise on divination, the White Beryl (Vaidurya dkar po), ${ }^{16}$ not much was known about the older strand. Thanks to recent studies into Chinese and Tibetan divination material from Dunhuang and nearby sites, conducted by Strickmann, Kalinowski, Nishida and others, our understanding of the older strand is slowly evolving. ${ }^{17}$

Looking at the Chinese and Tibetan material from Dunhuang, we can see that Tibetan and Chinese calendrical and astrological systems co-existed and interacted in Dunhuang in various ways. Beyond the calendrical and astrological texts themselves, we also have a literary source which attests to this interaction in a Chinese Dunhuang manuscript, which recalls a discussion between the Grand Astrologer and Wu Zixu 伍子胥 about the differences between the calendrical cycles of the Chinese (Han 漢), the Barbarians (Hu 胡), the Tibetans (Fan 蕃), the Tuyuhun (Hun 渾) and the Xianbei 鮮卑. 18

The Tibetan connection to Chinese divination is also revealed in Tibetan divination texts from Dunhuang which mention Confucius, rendered as Kong tse, as their author. In the Dunhuang manuscript ITJ.742, for example, Kong tse is mentioned as the author of a divination text. ${ }^{19}$ Among the manuscripts from Dunhuang we also find Tibetan translations of Confucian maxims (Pt.987 and Pt.988). ${ }^{20}$ According to Chinese sources from Dunhuang, we know that Confucian doctrines were taught in the prefectural Dunhuang school, and that special rites for his worship

\footnotetext{
15 Dorje 2001, pp. 16-17.

16 Dorje 2001.

17 The Chinese sources have been studied by Kalinowski and his team. See Kalinowski (ed.) 2003. The Tibetan divination material from Dunhuang has recently been studied by Ai Nishida. For a list of manuscripts and previous studies, see Nishida 2011. See also Nishida's PHD diss. (Nishida 2012). Strickmann's breathtaking study (Strickmann 2005) was published posthumously by Bernard Faure.

18 P.3288 (cols 229-38), see Deng Wenkuan and Liu Lexian in Kalinowski (ed.) 2003, p. 68.

19 Nishida 2011. See also MacDonald 1971, particularly pp. 282-3. Other Tibetan manuscripts from Dunhuang, which mention Kong tse (in its variant spellings) are Pt.987, Pt.988, Pt.992, Pt.1284. For a discussion of these, see Lin Shen-yu 2007.

$20 \quad$ Stein in McKeown (ed. and tr.) 2010.
} 
were conducted twice a year, at the time of the equinoxes, in which the entire body of doctors participated. ${ }^{21}$ Chinese diviners sought to legitimise their texts and techniques by referring to the Yijing and to Confucius. ${ }^{22}$

\section{Buddhisation of Divination}

Particular to the adaptation into a Tibetan context is the process of 'buddhisation' which concepts of divination, as well as their visual representations, have undergone. Tibetan Buddhist accounts maintain that medicine as well as astrology was taught by Buddha Sākyamuni himself. Both medicine and astrology have been categorised as Buddhist classical sciences (rig gnas). ${ }^{23}$ Amongst the Buddhist classical sciences, medicine is traditionally categorised under the five major sciences (rig gnas che ba), ${ }^{24}$ and astrology and divination under the five minor sciences (riggnas chung ba). ${ }^{25}$ It is worth noting here that the Tibetan term 'rig gnas', which is usually translated as 'science', also means 'art', 'culture' or 'field of knowledge'.

In Mahāyānic monastic learning in India, astronomy and astrology were taught as ancillary to medicine. Xuanzang 玄奘, the renowned 7 th-century Chinese pilgrim to India, informs us that both medicine and divination were part of the curriculum at Nālanda:

They studied Mahayana teachings and the doctrines of the 18 schools, as well as worldly books such as the Vedas. They also learned about works on logic, grammar, medicine, and divination. ${ }^{26}$

From a Buddhist-Mahāyānic point of view, the study of these 10 'fields of knowledge' has been described as essential in the path of the bodhisattva's striving towards omniscience. This omniscience is considered in Buddhist

21 Kalinowski in Lo and Cullen (eds) 2005, pp. 120-1.

22 Kalinowski and other contributions in Kalinowski (ed.) 2003.

23 The link between the sciences (rig gnas) and Buddhism is established in Tibetan medical literature and Tibetan astral sciences literature, as well as Buddhist literature. For an overview of the 10 Buddhist sciences in Tibetan Buddhist literature, see Ruegg 1995, pp. 93-147, 'Science religieuse et sciences séculières en Inde et au Tibet: vidyāsthāna indo-bouddhiques et rig gnas indo-tibétains'; see also Wallace, 2001, ch. 4, and Gold 2007, esp. ch. 1 .

The other four are inner science (i.e., Buddhism, nang rig pa), epistemology and logic (gtan tshigs rig pa), grammar (sgra rig pa), and arts (bzo rig pa).

The other four are poetry (snyan ngag), metrics (sdeb sbyor), lexicography (mngon brjod) and drama (zlos gar).

26 literature both as a means of helping others and as a way of knowing oneself. ${ }^{27}$

The Gyushi (rGyud bzhi, Four Tantras), thought by scholars to have been composed in the 12th century, and still regarded as the locus classicus of Tibetan medicine, begins with an account of how the Buddha, manifesting as the Medicine Buddha, gave the teaching encompassed in the text. ${ }^{28}$ Other Tibetan accounts ascribe the source of the knowledge of divination to Mañjuśrī (or Mañjughoșa) - seen in Figure 1 at the top centre. The presiding position of this Buddhist deity of knowledge here is a visual representation of the Tibetan systemisation of medicine and astrology within a Buddhist framework.

A significant Indic influence on Tibetan astro-medicine was also derived from the Kālacakra, an Indian Buddhist tantra composed in the 1oth century, which reached Tibet in the 11th century. The Kälacakra describes the association between the human body and the external world. In the Kālacakra tradition, the integral application of astronomical and medical knowledge is perceived as facilitating the flourishing of human potential and attainment of well-being. It focuses on the ways in which celestial bodies correlate with and influence the human body. This is based on two fundamental premises. The first is that both the human body and the cosmos partake of the nature of time. The second is that both the human body and the cosmos are composed of the same particles that make up the elements of earth, fire, water, wind, space and gnosis. ${ }^{29}$

The first two chapters of the Kälacakra, called respectively 'The Universe' and 'The Individual', demonstrate the Buddhist tantric view of the universe as macrocosm and the individual as its microcosm. The Kälacakra inquiry into the nature of the external world and the individual applies various disciplines such as Buddhist cosmology, astronomy, chronometry, embryology, physiology, botany, psychology and pharmacology. The aim is to provide an analysis of the natural world, which is viewed conventionally as an object of purification and ultimately as a manifestation of the Buddha's mind. One of the goals of the Kălacakra is to demonstrate the correspondence of the universe to

\footnotetext{
27 See Schaeffer 2003.

28 See rGyud bzhi (bDud rtsi snying po yan lag brgyad pa gsang ba man ngag girgyud), Lhasa 2000 edn, p. 1. Similarly, the Kälacakra Tantra, a main source for much of Tibetan astral sciences, has been presented as the words of the Buddha himself: see for example Bu-ston 1965, vol. nga (4), fol. 12b, l. 3-6.

For an analysis of how Tibetan medicine constructed itself to be part of Tibetan Buddhism, see Garrett 2006.

See Wallace 2008.
} 
the individual by identifying the properties of the external physical universe in the body of the individual. ${ }^{30}$

Buddhism also stands at the heart of the reasoning behind explanations provided in related divination manuals. Predictions are not considered to be deterministic, but cautionary and prescriptive. If the outcome is auspicious, no action needs to be taken. If the outcome is negative, the subject is advised to undertake the appropriate counteracting rites, such as the recitation of some Buddhist scriptures or mantras, the offering of purifying smoke (bsangs), the making of thread crosses ( $m$ dos) for ritual exorcism, alongside the carrying of amulets or talismans (such as the srid pa ho) or the offering of torma (gtor ma) cakes.

\section{The Turtle}

The common Tibetan depictions of the turtle in the context of divination are derived from the Chinese association of the shell of a sacred turtle and divination. Indeed in China the association between divination and turtle is inherent in the word $b u$ 个, which originally meant 'to divine by the turtle' and later became the general term for all forms of divination. ${ }^{31}$ The turtle also played an important role in Indian cosmological myths, as well as Western and Arabic ones. $^{32}$

Tibetan sources which present legendary Chinese accounts on the origins of divination reflect the link between the turtle and divination. According to these accounts as they are redacted in Tibetan sources, the mythical Chinese emperor Fu Xi 伏羲 (spa huh shi dhi) saw a gold-coloured turtle (rus sbal) which was offered to him by a subject from the coastal region. Upon his inspecting it, the patterns of the eight trigrams (T: spar kha, Ch: bagua 八卦) first arose in his mind. Consequently, the divination system based on the elemental relationships formed by the eight trigrams, the nine numeric squares (sme ba dgu) and the 12-year cycle (lo skor bcu gnyis) were devised and treatises were gradually composed by kings, ministers and learned scholars who had mastered these systems. ${ }^{33}$

The earliest known Sino-Tibetan turtle divination manuscript comes from Dunhuang and was brought to light by Sam van Schaik. ${ }^{34}$ This manuscript, Or.8210/S.6878

This principle also appears in earlier Ayurveda texts such as the Caraka Compendium and the Suśruta Compendium. See Wallace 1995, p. 31.

$31 \quad$ Kalinowski in Nylan and Loewe (eds) 2010, p. 339.

32 See Patyal 1995.

33 Dorje 2001, p. 16; Kelényi in Ardussi and Blezer (eds) 2002.

34 Van Schaik, 'The Golden Turtle: A Sino-Tibetan Divination Man-

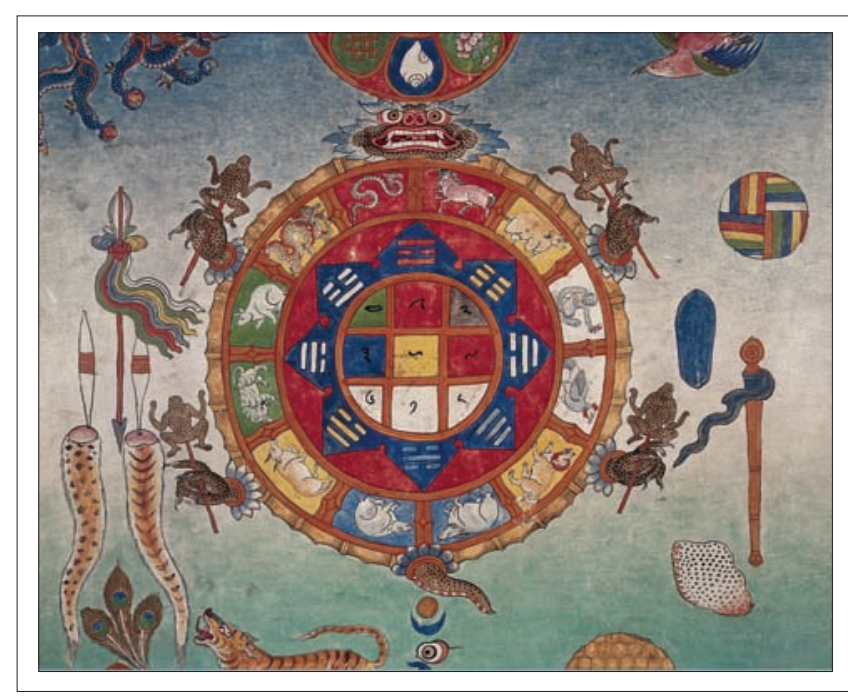

Figure 30.2 Detail of the tortoise, from Figure 30.1. (C) Wellcome Library, London, Loo35124

(Text 50), includes an image of a turtle and a number of divination texts (Fig. 3). It reflects the earliest extant evidence of Sino-Tibetan transmission of visual images related to divination. The manuscript includes sections on 13 methods of astrological divination, each illustrated with a diagram. Visually, these diagrams are precursors of some of the visual depictions we see in the Wellcome image (Fig. 2): divisions of a circle into nine sections, similar to later depictions of the magic square in a circle; divisions into 12 sections of the 12-year cycle; and division into eight sections, reminiscent of the later association with the eight trigrams.

The turtle is inscribed on its back with the words 'Golden Turtle' (gser gyi ru sbal). It has eight locations marked on its back: head (mgo), two ears (rna ba), two arms (lag pa), two sides of the body (mchan khung), two feet (rkang pa) and tail (mjug ma). The image of the turtle is followed by a mo divination text, using the eight types of days to find objects which have been lost.

The name for a turtle as depicted in this drawing, rubel ( rus sbal) literally means 'frog of bones' ( $r u s=b o n e s ; ~ s b a l=-$ frog). Indeed, the rubel from Dunhuang looks something like a cross between a frog and a turtle. In later depictions, the name rubel remains, but the image looks more like a turtle. An interesting Naxi variation, which maintained the link with a frog, was reported by J.F. Rock. ${ }^{35}$ The link with frogs might explain the presence of frogs surmounting the poles and held by the turtle in its four paws in the Wellcome image. The frogs depicted here represent spirits

uscript', available online at: earlytibet.com (accessed 10/o1/2014). See also Iwao, van Schaik and Takeuchi 2012. The image of the tortoise appears in text 5 o (S.6878), pls p. 83 .

35 See Hummel 1969. 


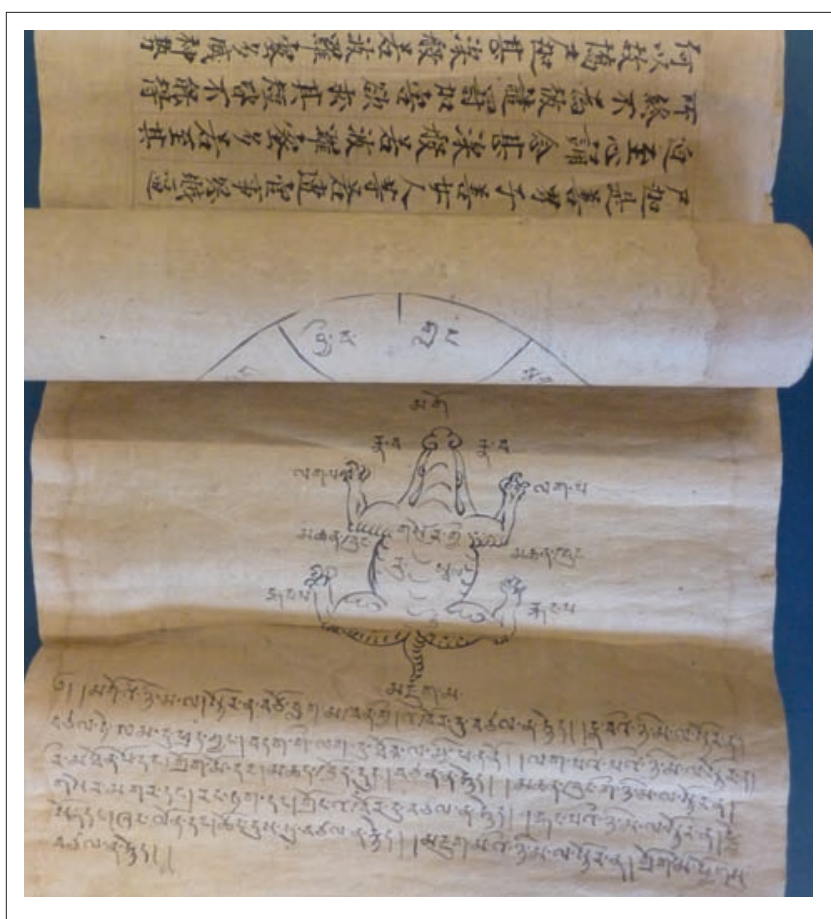

Figure 30.3 A Tibetan Frog/Turtle divination chart for the purpose of finding lost objects. Dunhuang; 9th-1oth century. This chart, along with other Tibetan divination charts, is found at the back of a Prajnaparamita Sütra written in Chinese. (c) British Library ms. Or.8210/S.6878

of the earth. Pictured nailed onto a stick, they symbolise 'pinning down' into stability (Fig. 2).

The eight locations on the Dunhuang turtle-frog appear to foreshadow the eight turtle locations on which we find the eight trigrams in later formulations, such as in the Wellcome illustration. One such later description is found in the 17 th-century White Beryl (Vaidurya dkar po):

Then the eight trigrams assembled separately, each with his or her own wealth, on the golden turtle of sentient existence. The father (Khen) was entwined with the left leg of the turtle, and the mother (Khon) with the left arm, while the younger daughter $(\mathrm{Li})$ was placed at its head, the second son (Dva) at its heart, the first incestuous offspring (Kham) at the tail, and the second (Zin) at the right armpit, the eldest daughter (Zon) at the first tier of Mount Sumeru and thence the right arm, and the eldest son (Gin), who became the general of the spirit lords of the soil (sa-bdag dmag-dpon), at the right leg. Following this separation, conflict then arose between Gin and Zon, Dva and Zin, Khon and Khen, and between Kham and Li, in consequence of which the eight trigrams (kha-brgyad) became known as the 'eight blazing trigrams' (spar-kha brgyad). ${ }^{36}$

It is interesting to note here that in the White Beryl the golden turtle is presented as a manifestation of Mañjuśrī.

$36 \quad$ Dorje 20o1, p. 46.

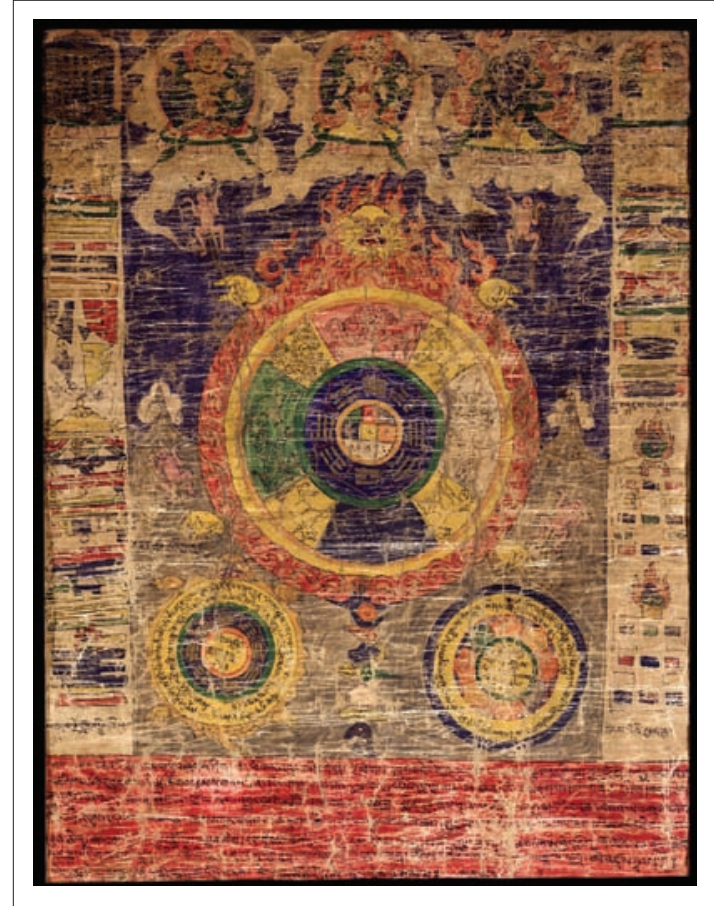

Figure 30.5 A sipaho (srid pa ho) protective chart. (c) Shelley \& Donald Rubin Foundation

The White Beryl discusses a number of different turtles representing various Buddhist notions. ${ }^{37}$

Associating a turtle chart with nine sections for divination purposes also became integrated into practices of Tibetan urine divination. In this technique, a fresh sample of urine is placed in a shallow container of round or oblong shape. A turtle divination chart is placed on top of the container. Changes in the urine specimen are then observed in the nine different sections. According to the changes in the urine, the doctor may identify which type of negative spirit is affecting the patient (Fig. 4). ${ }^{38}$

The image of a divination turtle became central in Tibetan images of divination and good luck. The Great Golden Turtle (mahā gser gyi rus sbal) became a common figure in Tibetan folk religion, with the role of preventing trouble and bad luck. The turtle has remained a popular Tibetan image, found as part of the very common srid pa ho image (Fig. 5).

The srid pa ho charts are very common amongst Tibetans to this day. They are hung on doors in order to prevent evil spirits from entering the home. They are also used as amulets for protection from bad luck, and are displayed on auspicious or inauspicious occasions, such as the time of marriage, important transitions, the time of death etc.

$37 \quad$ See Dorje 2001.

38 Parfionovitch, Dorje and Meyer 1992, pls, pp. 64-6. 


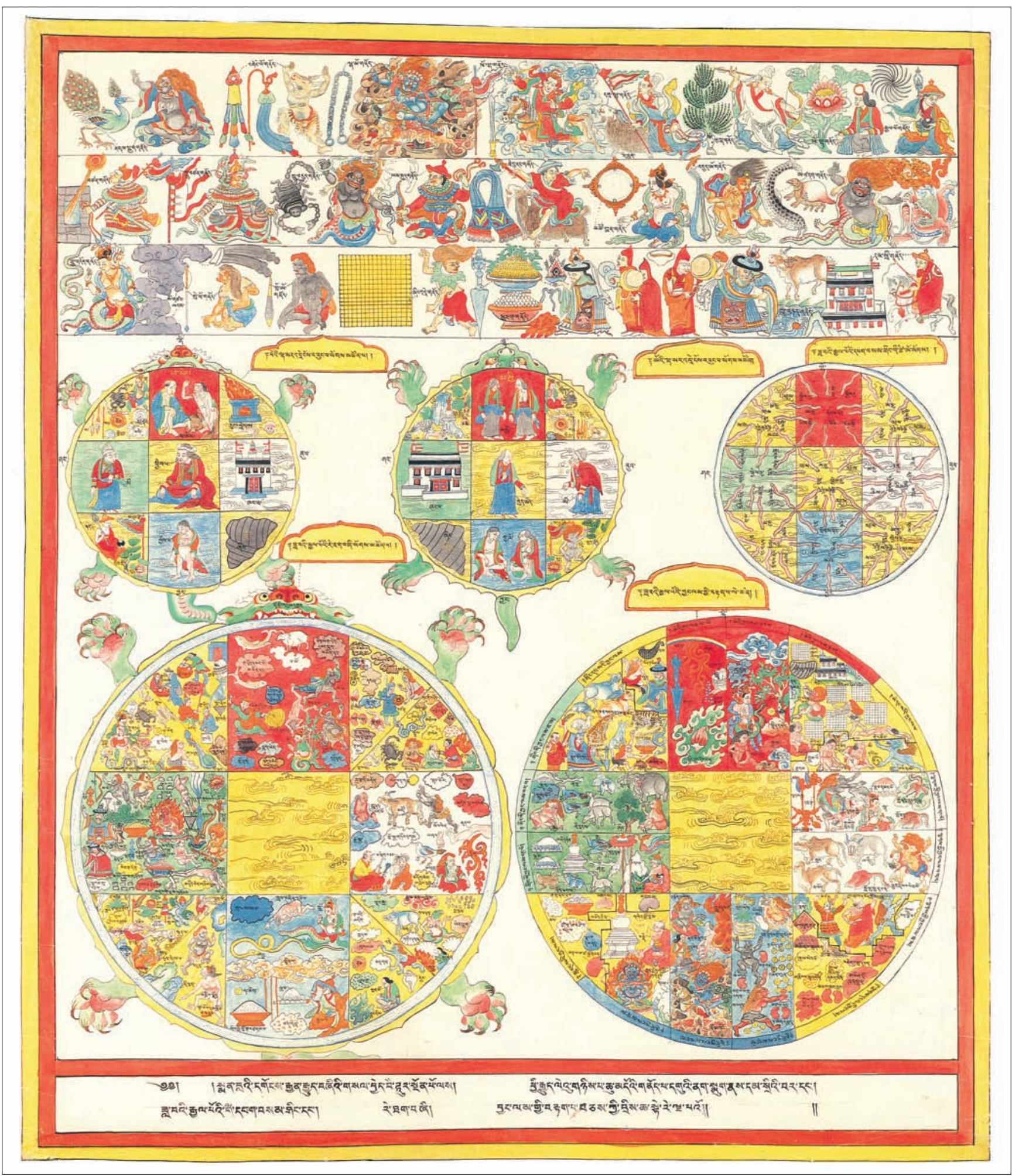

Figure 30.4 Tibetan medical painting no. 65: Urine divination using Turtle charts. Source, copyright? 


\section{The Magic Square}

At the centre of the turtle of the Wellcome image we find a magic square of order three. In a magic square the sum of all the rows, columns and diagonals is the same. In our case here, a magic square of order three, the sum is 15 . The magic square represented in the Wellcome image is:

\begin{tabular}{|c|c|c|}
\hline $\begin{array}{c}4 \\
\text { Green }\end{array}$ & $\begin{array}{c}9 \\
\text { Red }\end{array}$ & $\begin{array}{c}2 \\
\text { Black }\end{array}$ \\
\hline $\begin{array}{c}3 \\
\text { Blue }\end{array}$ & $\begin{array}{c}5 \\
\text { Yellow }\end{array}$ & $\begin{array}{c}7 \\
\text { Red }\end{array}$ \\
\hline $\begin{array}{c}6 \\
\text { White }\end{array}$ & $\begin{array}{c}1 \\
\text { White }\end{array}$ & $\begin{array}{c}8 \\
\text { White }\end{array}$ \\
\hline
\end{tabular}

We can see that the positions of the 6 and the 8 have been switched and that this magic square should look like this:

\begin{tabular}{|c|c|c|}
\hline $\begin{array}{c}4 \\
\text { Green }\end{array}$ & $\begin{array}{c}9 \\
\text { Red }\end{array}$ & $\begin{array}{c}2 \\
\text { Black }\end{array}$ \\
\hline $\begin{array}{c}3 \\
\text { Blue }\end{array}$ & $\begin{array}{c}5 \\
\text { Yellow }\end{array}$ & $\begin{array}{c}7 \\
\text { Red }\end{array}$ \\
\hline $\begin{array}{c}8 \\
\text { White }\end{array}$ & $\begin{array}{c}1 \\
\text { White }\end{array}$ & $\begin{array}{c}6 \\
\text { White }\end{array}$ \\
\hline
\end{tabular}

In Tibetan, the arrangement of the nine numbers is known as sme ba dgu, or the 'nine naevi' (nine moles). Sme ba literally refers to the white or black moles or spots found on the skin. The reference to moles or spots probably refers to their representation in the Luo shu diagram of white and black spots (Fig. 6).

As mentioned above, Chinese sources describe a sacred turtle with a magical square on its shell which appeared to the mythical King Yu 禹 from the waters of the Luo 雒 river at the time of taming the floods. ${ }^{39}$ It was called $L u o$ shu 洛書, or 'Document of the Luo (Lo) River', and was generally represented by a pseudo-archaic arrangement of black and white knots or beads on short strings of cord. Cammann has traced the depiction of the Luo shu in dotted form to the 1oth century $\mathrm{CE}{ }^{40}$

Tibetan sources too refer to these nine numbers as birthmarks on the turtle. Tibetan sources reflect the Chinese associations linking the numbers with colours, directions and the five agents. There are different variations for these associations. One set that is often found in Tibetan sources is: ${ }^{41}$

39 The turtle episode is also associated with Huangdi, the Yellow Emperor, in some Daoist writings. See Cammann 196o, p. 118.

40 Cammann 1961.

41 See Henning 2007, p. 168. For Chinese variations, see Major 1984.

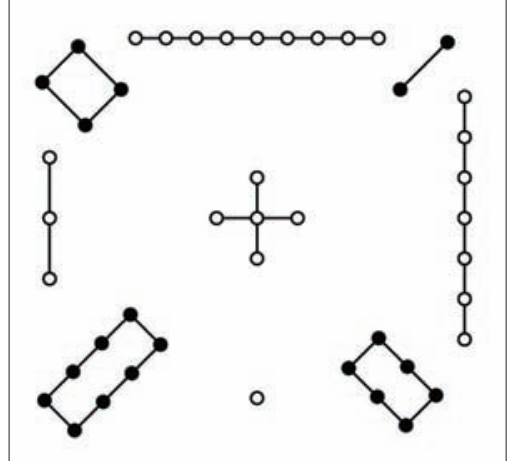

Figure 3 o.6 Luo shu: Chinese magic square of three

$\begin{array}{llll}1 & \text { White } & \text { Iron } & \text { north } \\ 2 & \text { Black } & \text { Water } & \text { south-west } \\ 3 & \text { Blue } & \text { Water } & \text { east } \\ 4 & \text { Green } & \text { Wood } & \text { south-east } \\ 5 & \text { Yellow } & \text { Earth } & \text { centre } \\ 6 & \text { White } & \text { Iron } & \text { north-west } \\ 7 & \text { Red } & \text { Fire } & \text { west } \\ 8 & \text { White } & \text { Iron } & \text { north-east } \\ 9 & \text { Red } & \text { Fire } & \text { south }\end{array}$

Nine Palace diagrams (jiugong tu 九宮圖), which form the basis for magic squares, have been found in China in texts dating to the 2nd century всЕ. ${ }^{42}$ The first of these, Xingde B (Xingde yipian 刑德乙篇), a diagram which has been found in the Mawangdui tombs, is the earliest known representation of the Nine Palaces diagram. Unlike later representations in the form of a square divided into nine equal cells, this diagram consists of a central circle from which radiate the eight sectors of the world, represented by squares (Fig. 7).

A similar star shaped representation of the Nine Palaces was also found on a Taiyi 太乙 diviner's board from Fuyang 阜陽 in present-day Anhui province. A date inscribed at the back of the instrument dates it to the 7 th year of the Emperor Wen of the Han dynasty, i.e. 173 BCE. ${ }^{43}$ Kalinowski has shown that by the Han period, the different components of magic squares were already linked together: the directions (four cardinal directions, four intermediary directions and the centre), numbers (1-9) and the eight trigrams. ${ }^{44}$

The grid of the magic square provided a visual image of the way in which mathematical structures stand at the basis of spatial order. ${ }^{45}$ As argued by Lewis, the grid constituted the most important mechanism for correlating earthly events to astral phenomena. The 'controlled space'

\footnotetext{
$42 \quad$ Kalinowski 1998-1999.

43 Ibid., p. 138, n. 36 and pp. 198-9.

44 Kalinowski 1985.

45 See Lewis 2006, pp. 245-305.
} 


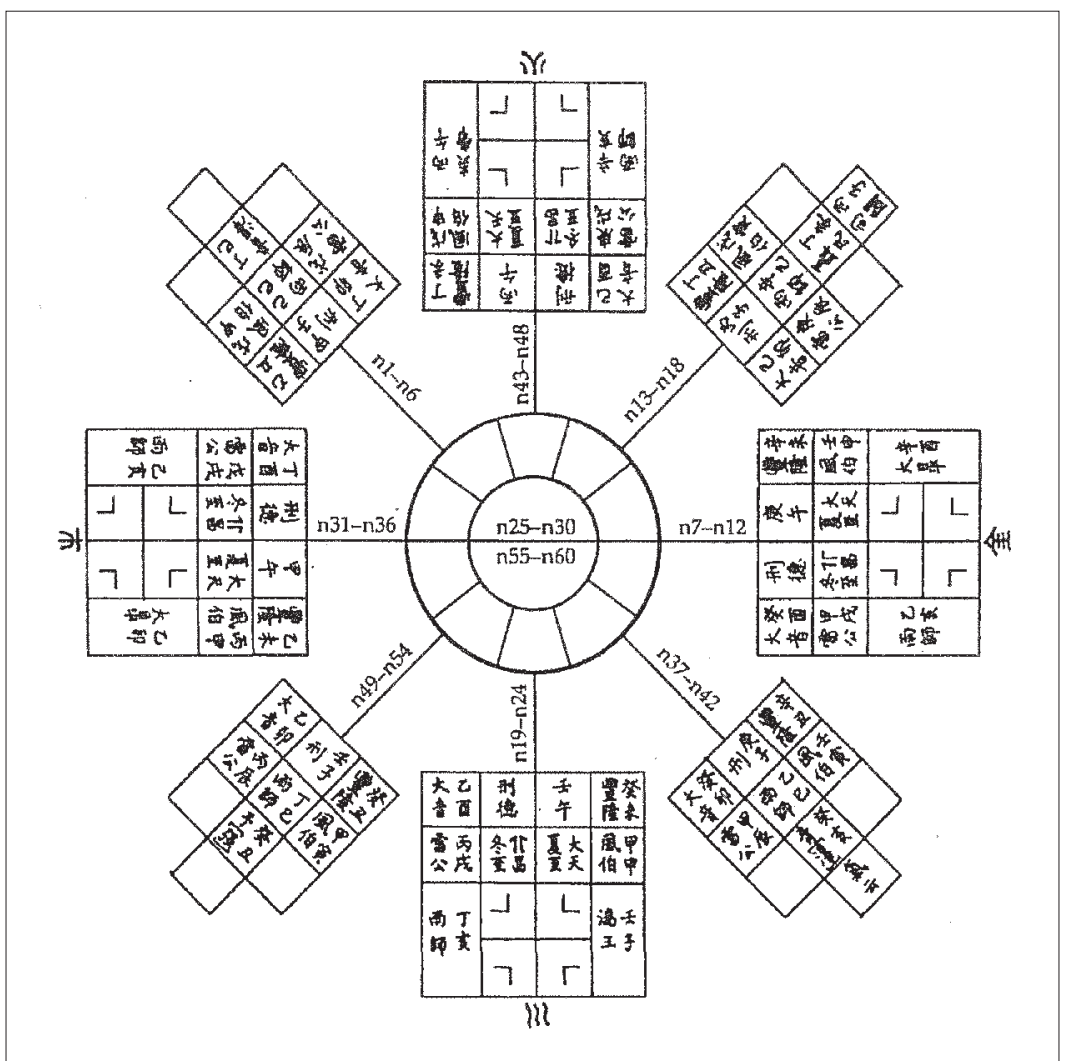

Figure 30.7 Representation of the Nine Palace diagram in Xingde B, Mawangdui tombs (2nd century BCE) (Rendering by Kalinowski). From Kalinowski 1998-9, p. 178, fig. 13

of the grid also formed a frame for linking cosmological models and ritual actions. The nine-square type of grid, formed by the intersection of two horizontal lines and two vertical lines at right angles, was the most common type. The earliest literary occurrence of this type of grid was in Mencius's model of the 'well-field' system. In this system, a piece of land was divided into nine sectors in the shape of the Chinese graph 'well' ( jing 井): the outer eight were cultivated by individual households, while the middle one, which had the well in it, was owned by the landlord and was cultivated collectively. As magic squares evolved in China, a schematic cosmography of the earth's nine regions became linked with magic squares and notions of the five agents, creating an integrated whole. ${ }^{46}$

\section{A Persian Parallel}

An image which is based on the same ideas at the basis of the Tibetan image under discussion, but which took a very different visual shape, is found in a Persian text from 14th-century Ilkhanid Iran. The text, Tansūqnāma-i

46
İlkhān dar funūn-i 'ulūm-i Khatā' the Ilkhan on Chinese Science and Techniques), known as the Tansūqnäma, was composed in the court of Rashìd al-Dīn and and includes a number of intriguing illustrations. Rashīd al-Dīn (1274-1318), the court physician and a powerful minister in the Ilkhanid court in Tabriz, assembled Chinese, Tibetans, Indians, Kashmiris and others at the Ilkhanid court and systematically translated and promoted the collection and dissemination of the different medical traditions of the cultures under Mongol rule at the time. ${ }^{47} \mathrm{His}$ monumental multi-cultural oeuvre - which is yet to receive the place it deserves in global intellectual history - was formed through noteworthy political levels of support. ${ }^{48}$

The Tansūqnāma, completed in 1313, is divided into two; the first part is an introduction by Rashīd al-Dīn. The second part is a collection of Chinese classical medical writings. As far as is presently known, this is the first indication of the transmission of classical Chinese medicine into the west. ${ }^{49}$

47 On Rashīd al-Dīn, see Akasoy, Burnett and Yoeli-Tlalim (eds) 2013. .

48 Prazniak 2014.

49 See Lo and Wang 2013; Berlekamp 2010; Klein-Franke and Zhu 


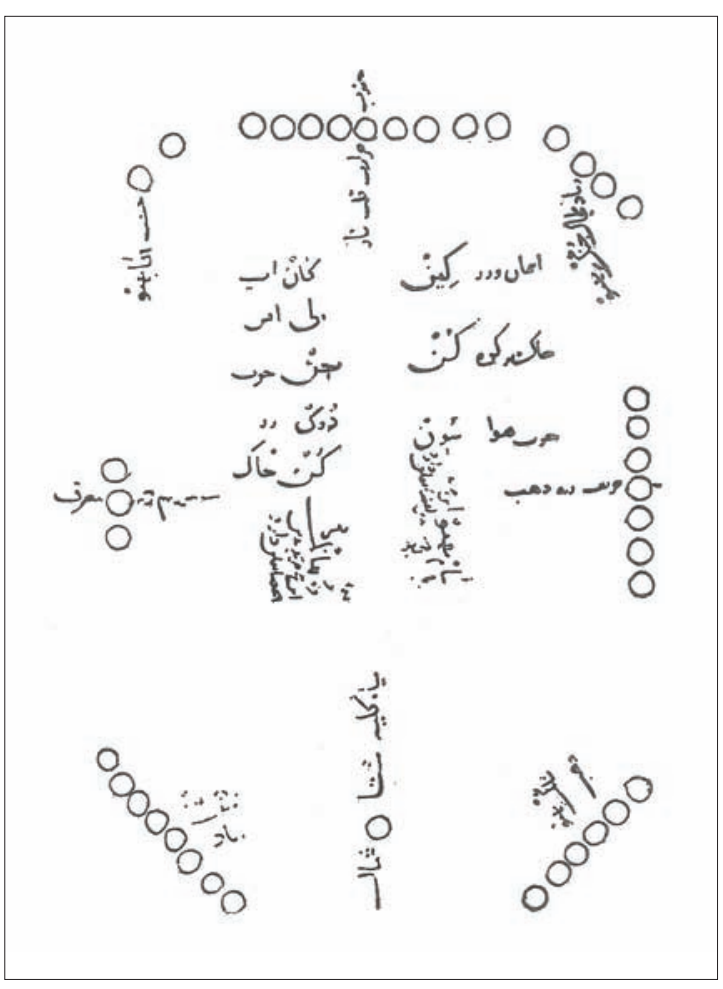

Figure 30.8 The Tansūqnāma of Rashid al-Din. Tabriz, 1313, ms. 3596, fol. 55b. (c) Süleymaniye Library, Aya Sofya Collection. Türkiye Yazma Eserler Kurumu Başkanlığı

Figure 8 from Tansūqnāma shows a visual representation of a magic square in the Chinese style. The magic square depicted here, clearly based on the Luo shu depictions, is set out thus:

\begin{tabular}{|l|l|l|}
\hline 2 & 9 & 4 \\
\hline 3 & & 7 \\
\hline 8 & 1 & 6 \\
\hline
\end{tabular}

Like the Tibetan image, it inverts the position of two numbers: here, the 2 and the 4 . The place of the central 5 is taken up by the names of the trigrams, the five agents and the relevant associations with body parts and the seasons.

Magic squares are documented in the Islamic world since the 9th-1oth centuries, and by Rashīd al-Dīn's time were well known in the Islamic world. A set of magic squares was presented in the Rasāil of the Ikhwān as-Ṣafā (Brethren of Purity), an encyclopaedia of sciences composed in Basra during the gth and oth centuries. As Baffioni points out, the Rasā'il was an Arabic compendium of foreign sciences, reworking Babylonian, Indian and Persian knowledge. ${ }^{50}$ Cammann has suggested that the section of magic squares

Ming, 1996. See also Lo and Yoeli-Talim, Chapter 20 in this volume.

50 Baffioni 2012. in the Rasāil incorporated Chinese notions, possibly via Indian mediation. ${ }^{51}$ Indeed, the Rasā'il includes many references to India and the Buddha. ${ }^{52}$ Early Islamic magic squares are also attributed to Jābir ibn Ḥayyān, known in Europe as Geber. ${ }^{53}$

Magic squares became an important part of the vocabulary of talisman-makers and compilers of magical manuals in Islamic cultures, particularly after the 12 th century. ${ }^{54}$ The $3 \times 3$ magic square became so important in Islamic cultures that the name itself of this type of magic square, budūh, acquired its own occult potency. It was known as a charm for easing childbirth. Magic squares also became known and popular in Hebrew and European languages.

Analysing the transmission of magic squares and amulets - many of them using magic squares - between the Chinese and the Muslim worlds, Johan Elverskog has shown that the Ilkhanid court played a key role in transmission. ${ }^{55}$ Although trigrams and their associations might have seemed alien to the compilers of the Tansūqnāma, the notion of the magic square probably fell on receptive ground.

\section{Magic Squares, Borders of Medicine, Borders of Cultures}

When somebody eventually sits down to write a global history of magic squares, he or she is bound to find a treasure-trove of unexplored stories of transmission. For the time being, what I have shown here is that this popular visual depiction, used in Tibetan medical and other divination practices to this day, has its roots in China and many parallels in what we may term 'popular medicine' among Muslims and Jews, and in Europe. ${ }^{56}$

In the long history of magic squares in China, they gained and lost meanings pertaining to various links between a human being and the world. The formula of the magic square was an effective way of distilling in a concise schematic structure a multitude of linkages between the micro-cosmos and the macro-cosmos. Its simple visual representation made it suitable both as a mnemonic device and for cross-cultural transmission.

\footnotetext{
$51 \quad$ Cammann 1969.

$5^{2}$ Walker, 'ekwwān al-ṣafā”.

53 Savage-Smith 1997, p. 106.

54 Savage-Smith 2004, "Introduction", pp. xiii-xliv.

55 Elverskog 2010, ch. 2, 'Understanding', especially pp. 104-14.

56 Cammann 196o. Cammann refutes a number of other exaggerated claims on the origins of magic squares. See also Cammann 1961.
} 
From studies on the transmission of diagrams such as magical squares across cultures and religions, we know that these were useful vessels not only for transmission but also for adaptation. In the Tibetan case, the visual representations went hand in hand with the transmission of Chinese divination theory and practice. In other cultural contexts, magic squares gained numerous new symbolic meanings that were part of their new cultural contexts.

\section{Bibliography}

\section{Primary Sources}

Bu-ston 1965, 'History of the Kālacakra' (Dus 'khor chos 'byung rgyud sde'izab don sgo 'byed rin chen gces pa'i lde mig), in Collected Works, New Delhi: International Academy of Indian Culture, vol. nga (4). rGyud bzhi (bDud rtsi snying po yan lag brgyad pa gsang ba man ngag gi rgyud), Lhasa: Bod ljongs mi dmangs dpe skrun khang, 2000.

Sangs rgyas rgya mtsho, Vaidurya dkar po [Phug lugs rtsis kyi legs bshad Vaidūra dkar po. Reproduced as The Vaidūrya dkar po of sde-srid Sans-rgyas-rgya-mtsho], New Delhi: T. Tsepal Taikhang, 1972.

\section{Secondary Sources}

Akasoy, A., C. Burnett and R. Yoeli-Tlalim (eds) 2008, Astro-Medicine: Astrology and Medicine, East and West (Micrologus' Library, 25), Florence: SISMEL/Edizioni del Galluzzo.

C. Burnett and R. Yoeli-Tlalim (eds) 2013, Rashid al-Din as an Agent and Mediator of Cultural Exchanges in Ilkhanid Iran, London: Warburg Institute.

Ardussi, J. and H. Blezer (eds) 2002, Impressions of Bhutan and Tibetan Art: Tibetan Studies III, Proceedings of the Ninth Seminar of the IATS 200o, Leiden: Brill.

Baffioni, C. 'Ikhwān al-Safā", The Stanford Encyclopedia of Philosophy (Summer 2012 edn), ed. E.N. Zalta: http://plato.stanford.edu/ archives/sum2012/entries/ikhwan-al-safa (accessed 27/o6/17).

Berlekamp, P., 2010, 'The limits of artistic exchange in fourteenth-century Tabriz: the paradox of Rashid al-Din's Book on Chinese Medicine, Part I', Muqarnas 27, 209-50.

Cammann, S. 1960, 'The Evolution of Magic Squares in China', Journal of the American Oriental Society 8.2 (April-June), 116-24.

Cammann, S. 1961, 'The magic square of three in old Chinese philosophy and religion', History of Religions 1.1 (Summer), 37-80.

1969, 'Islamic and Indian magic squares. Part I', History of Religions, 8.3 (February), 181-209.

Chime Radha Rinpoche 1981, 'Tibet', in Loewe and Blacker (eds), 3-37. Cornu, P. 1997, Tibetan Astrology, Boston: Shambala.

Deng Wenkuan 鄧文寬 and Liu Lexian 劉樂賢 2003, 'Uranomancie', in Kalinowski (ed.), 35-83.

Dorje, Gyurme (comm. and tr.), 2001, Tibetan Elemental Divination Paintings: Illuminated Manuscripts from The White Beryl of Sangs-rgyas rGya-mtsho: with the Moonbeams Treatise of Lo-chen Dharmaśri, London: John Eskenazi, 2001.

Elverskog, J. 2010, Buddhism and Islam on the Silk Road, Philadelphia: University of Pennsylvania Press.

Gold, J. 2007, The Dharma's Gatekeepers: Sakya Pandita on Buddhist Scholarship in Tibet, Albany, NY.: SUNY Press.

Garrett, F. 2006, 'Buddhism and the Historicising of Medicine', Asian Medicine: Tradition and Modernity 2, 204-24.
Henning, E. 2007, Kālacakra and the Tibetan Calendar, New York: Columbia University Press.

Hofer, T. (ed.) 2014, Bodies in Balance: The Art of Tibetan Medicine, New York: Rubin Museum of Art and Washington University Press.

Hummel, S. 1969, 'The sMe-ba-dgu, the Magic Square of the Tibetans', East and West 19, 139-46.

Imaeda, Yoshiro, M. Kapstein and Tsuguhito Takeuchi (eds) 2011, New Studies of the Old Tibetan Documents: Philology, History and Religion, Tokyo: Research Institute for Languages and Cultures of Asia and Africa.

Iwao, Kazushi, S. van Schaik and Tsuguhito Takeuchi 2012, Old Tibetan Texts in the Stein Collection Or. 8210, Tokyo: Toyo Bunko.

Jampa Dagthon et al. 1998, Tibetan Astronomy and Astrology: a Brief Introduction, Dharamsala: Men Tsee Khang, 1998.

Jhampa Kalsang 1999, Tibet Astro Science, Rome: Tibet Domani.

Kalinowski, M. 1985, 'La transmission du dispositif des neuf palais sous les six-dynasties', in Strickmann (ed.), 773-811.

1998-1999, 'The Xingde texts from Mawangdui', Early China $23-4,125^{-202}$.

(ed.) 2003, Divination et société dans la Chine médiévale: Étude des manuscrits de Dunhuang de la Bibliothèque nationale de France et de la British Library, Paris: Bibliothèque nationale de France.

2005, 'Mantic texts in their cultural context', in Lo and Cullen (eds), 109-33.

2010, 'Divination and astrology: received texts and excavated manuscripts', in Nylan and Loewe (eds), 339-66.

Kelényi, B. 2002, 'The myth of the cosmic turtle according to the late astrological tradition', in Ardussi and Blezer (eds), 69-9o.

Klein-Franke, F. and Zhu Ming 1996, 'Rashīd al-Dīn as a transmitter of Chinese medicine to the West', Le Muséon 109, 395-404.

Laufer, B. 1914, 'Bird divination among the Tibetans', T'oung Pao 15, 1-110.

Lewis, M.E. 2006, The Construction of Space in Early China, Albany, NY: SUNY.

Li Rongxi 李荣熙 (tr.) 1995, A Biography of the Tripitaka Master of the Great Ci'en Monastery of the Great Tang Dynasty, Berkeley, CA: Numata Center for Buddhist Translation and Research.

Lin Shen-yu 林純瑜 2007, 'The Tibetan image of Confucius', Revue d'Études Tibétaines 12, 105-29.

Lo, V. and C. Cullen (eds) 2005, Medieval Chinese Medicine: The Dunhuang Medical Manuscripts, London: RoutledgeCurzon.

Lo, V. and Wang Yidan 王一丹 2013, 'Blood or Qi circulation? On the nature of authority in Rashīd al-Dīn's Tānksūqnāma ('The Treasure Book of the Ilkhan on Chinese Science and Techniques')', in Akasoy, Burnett and Yoeli-Tlalim, (eds), 127-72.

Loewe M. and C. Blacker (eds) 1981, Divination and Oracles, London: George Unwin.

MacDonald, A. 1971, 'Une lecture des Pelliot tibétain 1286, 1287, 1038, 1047, et 129o', in MacDonald (ed.), 19o-391.

- (ed.) 1971a, Études tibétaines dédiées à la mémoire de Marcelle Lalou, Paris: Adrien Maisonneuve.

Maddison, F. and E. Savage-Smith 1997, Science, Tools and Magic (Pt 1: Body and Spirit, Mapping the Universe), London: Nour Foundation.

Mair, V. 2006, 'Kinesis versus stasis, interaction versus independent invention', in Mair (ed.), 1-16.

(ed.) 2006a, Contact and Exchange in the Ancient World, Honolulu: University of Hawai'i Press.

Major, J. 1984, 'The Five Phases, magic squares, and schematic cosmography', in Rosemont Jr. (ed.), 133-66.

Nishida, Ai 2011, 'An old Tibetan divination with coins: IOL Tib J 742', in Yoshiro Imaeda, Kapstein and Tsuguhito Takeuchi (eds), New Studies of the Old Tibetan Documents: Philology, History and 
Religion, Tokyo: Research Institute for Languages and Cultures of Asia and Africa, 315-27.

2012, 'Ko-Tibet-go uranaimonjyo no kenkyū 古チベット語占

い文書の研究’ (A study on old Tibetan divination manuscripts), PHD diss., Kobe City University of Foreign Studies.

Nylan, M. and M. Loewe (eds) 2010, China's Early Empires: A ReAppraisal, Cambridge: CuP.

Parfionovitch, Y., G. Dorje and F. Meyer 1992, Tibetan Medical Paintings: Illustrations of the Blue Beryl of Sangya Gyatso, London: Serindia Publications.

Patyal, H.C. 1995, 'Tortoise in mythology and ritual', East \& West 45, 97-108.

Prazniak, R. 2014, 'Ilkhanid Buddhism: traces of a passage in Eurasian history', Comparative Studies in Society and History, 56.3, 650-8o.

Rosemont, H. Jr. (ed.) 1984, Explorations in Early Chinese Cosmology, JAAR Thematic Studies 50.2, Chico, CA: Scholars Press

Ruegg, D.S., 1995, Ordre spirituel et ordre temporel dans la pensée bouddhique de l'Inde et du Tibet: quatre conférences au Collège de France, Paris: Collège de France.

Said, E.W. 2003 [1978], Orientalism, London: Penguin Books.

Sangs rgyas rgya mtsho, tr. G. Kilty 2010, Mirror of Beryl: A Historical Introduction to Tibetan Medicine, Boston: Wisdom.

Savage-Smith, E. 1997, 'Talismanic charts', in Maddison and SavageSmith, 106-23.

(ed.) 2004, Magic and Divination in Early Islam, Aldershot: Ashgate-Variorum.

Schaeffer, K. 2003, 'Textual scholarship, medical tradition and Mahāyāna Buddhist ideals in Tibet', Journal of Indian Philosophy 31, 621-41.

Schuh, D. 1973, Untersuchungen zur Geschichte der Tibetischen Kalenderrechnung, Wiesbaden: Steiner Verlag.

Stein, R.A. 1939, 'Trente-trois fiches de divination tibétaines', Harvard Journal of Asiatic Studies 4, 297-371. 1972, Tibetan Civilization, London: Faber and Faber. huang manuscripts, in Stein 2010a, 273-335.

2010a, RolfStein's Tibetica Antiqua with Additional Materials, ed. and tr. A. McKeown, Leiden: Brill.

Strickmann, M. (ed.) 1985, Tantric and Taoist Studies in Honour of R.A. Stein, vol. 3 (Mélanges chinois et bouddhiques, vol. 22), Brussels: Institut des Hautes Études Chinoises.

(ed. B. Faure) 2005, Chinese Poetry and Prophecy: The Written Oracle in East Asia, Stanford: Stanford University Press.

Van Schaik, S. 'The Golden Turtle: a Sino-Tibetan divination manuscript', available online at: http://earlytibet.com/20o8/11/28/ the-golden-turtle (accessed 27/o6/17).

Vasstveit, I.K. 2014, 'A day at the astrology department of the Men-TseeKhang in Dharamsala, India', in Hofer (ed.), 105-10.

Walker, P.E., 'Ekֵwān al-Șafā”, Encyclopaedia Iranica, available online at: http://www.iranicaonline.org/articles/ekwan-al-safa (accessed 27/06/17).

Wallace, V.1995, 'The Buddhist tantric medicine in the Kālacakratantra', The Pacific World:Journal of the Institute of Buddhist Studies, New Series 10-11, 155-74.

2001, The Inner Kälacakratantra: a Buddhist Tantric View of the Individual, New York/Oxford: OuP.

2008, 'A convergence of medical and astro-sciences in Indian Tantric Buddhism: a case of the Kālacakratantra', in Akasoy, Burnett and Yoeli-Tlalim (eds), 2o9-22.

Yang Ga 2014, 'The Origins of the Four Tantras and an account of its author, Yuthog Yonten Gonpo', in Hofer (ed.), 154-77.

Yoeli-Tlalim, R. 2014, 'Medicine, astrology and divination', in Hofer (ed.), 90-104.

Yuthok Yonten Gonpo, tr. Thokmay Paljor et al. 2011, The Subsequent Tantra: From the Four Tantras of Tibetan Medicine, Dharamsala: Men-Tsee-Khang Publications. 